\title{
Laparoscopic cholecystectomy pain: effects of the combination of incisional and intraperitoneal levobupivacaine before or after surgery
}

\section{Laparoskopik kolesistektomi ă̆rısı: Cerrabi öncesi veya sonrasında uygulanan insizyonel ve intraperitoneal levobupivakain kombinasyonunun etkisi}

\author{
Işık ALPER, ${ }^{1}$ Sezgin ULUKAYA, ${ }^{1}$ Gülsüm YÜKSEL, ${ }^{3}$ Meltem UYAR, ${ }^{2}$ Taner BALCIOĞLU1
}

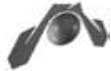

\section{Summary}

Objectives: We aimed to investigate whether the timing of administration, using a combination of incisional and intraperitoneal levobupivacaine $(0.25 \%)$, has an effect on the postoperative pain after laparoscopic cholecystectomy in a prospective, randomized, and controlled study.

Methods: Sixty six patients were allocated to one of the three groups. Group BS received levobupivacaine before trocar site incision and intraperitoneal levobupivacaine immediately after pneumoperitoneum. Group AS received intraperitoneal levobupivacaine before trocars were withdrawn and incisional levobupivacaine administered at the end of surgery. Group $C$ received no treatment. Data of intraoperative variables, postoperative pain relief, rescue analgesic consumption, and patient satisfaction were compared.

Results: The intraoperative fentanyl consumption was found lower in Group BS, compared to Groups AS and C ( $<<0.05)$. VAS scores were lower in both Groups BS and AS, compared to Group C immediately after the operation $(p<0.05)$. VAS scores were significantly decreased during the first two hours in Group AS, compared to Group C. The mean doses and number of patients needing rescue meperidine were lower in Group AS, compared to the Groups BS and C $(\mathrm{p}<0.05)$.

Conclusion: The combination of incisional and intraperitoneal levobupivacaine administered before or after surgery can reduce postoperative pain and analgesic and antiemetic consumption together with improved patient satisfaction. However, administering levobupivacaine before surgery might be advantageous for less intraoperative fentanyl consumption, while levobupivacaine after surgery is advantageous for less postoperative rescue analgesic requirement.
\end{abstract}

Key words: Intraperitoneal instillation; laparoscopic cholecystectomy; levobupivacaine; postoperative pain.

\section{Özet}

Amaç: Insizyonel ve intraperitoneal \%0.25 levobupivakain kombinasyonunun uygulama zamanının laparoskopik kolesistektomi sonrası ağr üzerine etkisinin ileriye yönelik, randomize, kontrollü çalışma olarak araştırılması amaçlandı.

Gereç ve Yöntem: Altmış altı hasta üç gruptan birine dabil edildi. Grup BS'ye, trokar yerlerine insizyon yapilmadan önce ve pnömoperitonyumdan bemen sonra levobupivakain uygulandı. Grup AS'ye trokarlar çekilmeden bemen önce intraperitoneal ve operasyon sonunda insizyonel levobupivakain uygulandı. Grup C kontrol grubu olarak kabul edildi. Ameliyat sirasında değişkenler, ameliyat sonrası ağrı sağaltımı, ek analjezik tüketimi ve hasta memnuniyetine ilişkin veriler karşılaştırıldı.

Bulgular: Ameliyat sirasinda fentanil tüketimi Grup BS'de Grup AS ve Grup C'ye göre daha az bulundu ( $p<0.05)$. Operasyondan bemen sonra VAS skorları Grup BS ve Grup AS'de Grup C'ye göre daha düşük saptandı ( $p<0.05)$. VAS skorlart ilk iki saat süresince Grup AS'de Grup C'ye göre anlamlı düş̈̈k bulundu. Ek meperidin gereksinimi olan hasta sayısı ve ortalama meperidin dozu Grup AS'de Grup BS ve Grup C'ye göre daha az saptandı ( $p<0.05)$.

Sonuç: Insizyonel ve intraperitoneal levobupivakain kombinasyonunun operasyon öncesi veya sonrası uygulanması ameliyat sonrası ăgr, analjezik ve antiemetik gereksinimini azaltmakta ve hasta konforunu artırmaktadır. Ayrıca levobupivakainin cerrabi öncesi uygulanması ameliyat sirasinda fentanil tüketimini azaltırken, cerrabi sonrası uygulanması ameliyat sonrası ek analjezik gereksinimi azaltması açısindan avantajlıdır.

Anahtar sözcükler: Intraperitoneal analjezi; laparoskopik kolesistektomi; levobupivakain; postoperatif ağrı.

\footnotetext{
' Department of Anesthesiology and Reanimation, Ege University Faculty of Medicine, Izmir, Turkey;

${ }^{2}$ Department of Algology, Ege University Faculty of Medicine, Izmir, Turkey;

${ }^{3}$ Department of Anesthesiology and Reanimation Clinic, Malazgirt State Hospital, Muş, Turkey

${ }^{1}$ Ege Üniversitesi Tıp Fakültesi, Anesteziyoloji ve Reanimasyon Anabilim Dalı, İzmir;

${ }^{2}$ Ege Üniversitesi Tıp Fakültesi, Algoloji Bilim Dalı, Izmir;

${ }^{3}$ Malazgirt Devlet Hastanesi, Anesteziyoloji ve Reanimasyon Kliniği, Muş

Submitted (Başvuru tarihi) 22.01.2013 Accepted after revision (Düzeltme sonrası kabul tarihi) 16.07.2013
}

Correspondence (iletişsim): Dr. lşık Alper. Ege Üniversitesi Tıp Fakültesi, Anesteziyoloji ve Reanimasyon Anabilim Dall, Bornova, 35100 Izmir, Turkey.

Tel: +90 - 232 - 3902140 e-mail (e-posta): i.alper@yahoo.com 


\section{Introduction}

Postoperative pain remains the most prevalent complaint after laparoscopic cholecystectomy (LC). This can prolong hospital stay, which is particularly of utmost importance since many centers are performing this operation as a day-case procedure. ${ }^{[1,2]}$ Both incisional and intraperitoneal administration of local anesthetics (LA) are increasingly being used in the multimodal analgesia practice, to provide adequate postoperative pain relief after LC. ${ }^{[3]}$ However it has been suggested that the timing of LA administration has an important role in the success of this analgesia technique. ${ }^{[2]}$ Intraperitoneal administration of LA, immediately after pneumoperitoneum, has been shown to be more effective than the administration of LA before the removal of the trocars at the end of surgery. ${ }^{[4]}$ In another study, using incisional LA before surgery resulted in reduced pain and analgesic consumption after LC. ${ }^{[5]}$ It was also reported that the combination of incisional and intraperitoneal administrations showed an advantage for postoperative analgesia after LC. ${ }^{[6]}$ Levobupivacaine, an isomer of racemic bupivacaine has been presented as a safer LA with a lower cardiac toxicity. ${ }^{[7]}$ In our previously reported study, benefits of intraperitoneal administration of levobupivacaine before surgery were only seen in the early postoperative period, when compared to normal saline. ${ }^{[8]}$ There is a necessity to compare the effects of the timing of combination of LA administration on postoperative pain relief after LC.

The purpose of the presented study was to investigate whether timing of administration of the combination of incisional and intraperitoneal levobupivacaine has an effect on the quality and duration of postoperative pain after LC in a prospective, randomized, controlled study design.

\section{Materials and Methods}

After our University Ethics Committee approval and written informed consent, 66 ASA I-II patients undergoing LC were enrolled in this prospective, randomized, controlled trial. Exclusion criteria were acute cholecystitis, hypersensitivity to LAs and morbid obesity. During the preoperative visit, the patients were instructed to use the visual analog scale (VAS), ranging from 0 (no pain) to 10 (worst pain imaginable).
For all patients, standard monitoring with electrocardiography, noninvasive blood pressure (NIBP) and peripheral oxygen saturation $\left(\mathrm{SpO}_{2}\right)$ was carried out. Anesthesia was induced intravenously using propofol $2-2.5 \mathrm{mg} / \mathrm{kg}$, fentanyl $2 \mu \mathrm{g} / \mathrm{kg}$ and rocuronium $0.6 \mathrm{mg} / \mathrm{kg}$ and was maintained by using $2-2.5 \%$ sevoflurane combined with nitrous oxide $60 \%$ in oxygen and additional boluses of fentanyl and rocuronium, as required. Ventilation was adjusted to maintain the end-tidal $\mathrm{CO}_{2}$ concentration between $32-35 \mathrm{mmHg}$.

Thereafter, patients were randomly allocated to one of the three groups, each consisting of 22 patients, named as 'before surgery', 'after surgery' or 'control' groups. The 'before surgery' patients (Group BS) received $0.25 \%$ levobupivacaine $(15 \mathrm{~mL})$ before incision to the scheduled trocar sites and intraperitoneal $0.25 \%$ levobupivacaine $(40 \mathrm{~mL})$, immediately after the creation of pneumoperitoneum. 'After surgery' patients (Group AS) received the same doses of incisional levobupivacaine at the end of the operation and intraperitoneal levobupivacaine before the trocars were withdrawn. The patients in the control group (Group C) received no treatment. Standard laparoscopic procedure was carried out using fourtrocar technique. The four port sites were infiltrated with $2.5 \mathrm{ml}$ for two $5 \mathrm{~mm}$ sites and $5 \mathrm{ml}$ for the other two $10 \mathrm{~mm}$ sites. Intraperitoneal levobupivacaine was instilled with a catheter inserted in the right subcostal trocar into the hepatodiaphragmatic lodge and above or the lodge of the gall bladder under direct vision. After instillation of levobupivacaine, patients were positioned in a 15 degree head-down for two minutes then reversed to the anti-Trendelenburg position for the surgery. During laparoscopy, intraabdominal pressure of all patients was maintained at $12 \mathrm{mmHg}$ with continuous $\mathrm{CO}_{2}$ insufflation.

Hemodynamic changes exceeding more than 20\% increase, when compared to the preoperatively assessed baseline values, were treated intravenously by additional bolus doses of $50 \mu \mathrm{g}$ fentanyl. Bradycardia was defined as a heart rate $<50 \mathrm{bpm}$ and planned to treat with atropine $0.5 \mathrm{mg}$ i.v. Standard recording was carried out during surgery in 5 minutes intervals.

Before the end of the operation, paracetamol $1 \mathrm{~g}$ i.v. 
infusion was given to all patients. After the completion of the surgical procedure, sevoflurane and nitrous oxide were ceased. Atropine $10 \mu \mathrm{g} / \mathrm{kg}$ and neostigmine $20-40 \mu \mathrm{g} / \mathrm{kg}$ were given for pharmacologic reversal of neuromuscular blockade.

The anesthesiologist following up the patient was blinded to the groups. The time of arrival at the postoperative unit was defined as zero hour postoperatively. The intensity of postoperative abdominal pain was assessed using a VAS, with evaluation at 0 , $0.5,1,2,4,6,8,12$ and 24 hours postoperatively. In patients with VAS scores $>4$, meperidine $1 \mathrm{mg} /$ $\mathrm{kg}$ i.m. was administered as rescue analgesia treatment. Postoperative nausea and vomiting (PONV) were also planned to treat with metoclopramide 10 mg i.v. when required.

Data of intraoperative fentanyl consumption, postoperative abdominal pain intensity, the incidence of right shoulder pain, incidence of nausea and vomiting, rescue analgesic (meperidine) and antiemetic (metoclopramide) requirements, and patient satisfaction in the follow-up period of $24 \mathrm{~h}$ were compared between groups.

A power analysis considering the pain score as the primary criteration revealed that group sample sizes of 16 and 16 achieve $81 \%$ power to detect a difference of 2.0 between the null hypothesis with known group standard deviations of 2.0 and with a significance level (alpha) of 0.05 using a two-sided MannWhitney test. We therefore studied 22 patients for each group with a power of $89 \%$.

Data analysis was performed using SPSS version

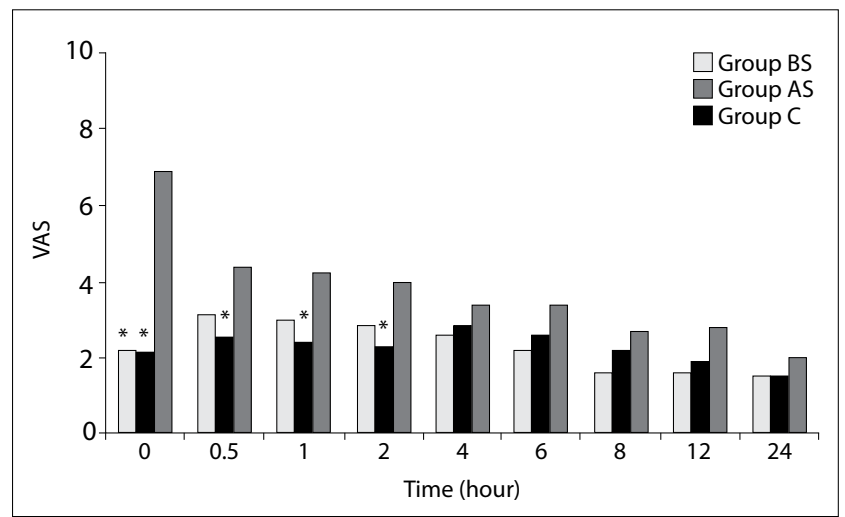

Figure 1. Postoperative visuel analog scale (VAS) scores of groups. *: $p<0.05$, compared to Group C.

15.0 for Windows. Demographic data, duration of surgery, total mean doses of fentanyl, rescue meperidine and metoclopramide consumptions were analyzed using t-test and chi-square tests. Pain intensity (VAS pain scores), mean end-tidal concentration of sevoflurane and course of hemodynamic variables were compared between the groups by analysis of variance (ANOVA) where as Bonferroni test was used for post-hoc multiple comparisons. Data are presented as mean $\pm S D$ (standard deviation) or number of patients. A p-value of less than 0.05 was considered statistically significant.

\section{Results}

All groups had similar characteristics in terms of age, gender, body measures and the mean duration of surgery (Table 1). Nevertheless, mean concentration of administered intraoperative sevoflurane, hemodynamic variables (systolic-diastolic-mean arterial pressures and heart rate), end-tidal carbondioxide partial pressure and $\mathrm{SpO}_{2}$ were similar between the

Table 1. Patient characteristics and intraoperative fentanyl requirements

\begin{tabular}{lccc}
\hline & $\begin{array}{c}\text { Group BS } \\
(\mathbf{n = 2 2})\end{array}$ & $\begin{array}{c}\text { Group AS } \\
(\mathbf{n = 2 2 )}\end{array}$ & $\begin{array}{c}\text { Group C } \\
(\mathbf{n = 2 2 )}\end{array}$ \\
\hline Age (yr) & $42 \pm 8.2$ & $40 \pm 9.5$ & $44 \pm 6.7$ \\
Gender (Male/Female) & $5 / 17$ & $6 / 16$ & $8 / 14$ \\
Weight (kg) & $71 \pm 8.8$ & $73 \pm 9.6$ & $72 \pm 10$ \\
Height (cm) & $167 \pm 4.5$ & $169 \pm 5$ & $167 \pm 5.9$ \\
Duration of surgery (min) & $69 \pm 15$ & $73 \pm 11$ & $67 \pm 13$ \\
Intraoperative fentanyl requirement $(\mu \mathrm{g})$ & $20 \pm 25$ & $42.5 \pm 40^{*}$ & $45 \pm 48^{*}$ \\
Patients requiring additional fentanyl $(\mathrm{n})$ & 8 & 12 & 12 \\
\hline
\end{tabular}

Data are expressed as mean $\pm S D$ and number of patients. ${ }^{*} p<0.05$, compared to Group BS. 
Table 2. Postoperative rescue medications of groups

\begin{tabular}{lccc}
\hline & $\begin{array}{c}\text { Group BS } \\
(\mathbf{n = 2 2 )}\end{array}$ & $\begin{array}{c}\text { Group AS } \\
(\mathbf{n = 2 2})\end{array}$ & $\begin{array}{c}\text { Group C } \\
(\mathbf{n = 2 2})\end{array}$ \\
\hline Meperidine consumption $(\mathrm{mg})$ & $85 \pm 62^{*}$ & $42 \pm 59$ & $156 \pm 61^{*+}$ \\
Patients requiring meperidine $(\mathrm{n})$ & $16^{*}$ & 8 & $20^{*}$ \\
Metoclopramide consumption $(\mathrm{mg})$ & $5 \pm 6$ & $2 \pm 4$ & $14 \pm 10^{*+}$ \\
Patients requiring metoclopramide $(\mathrm{n})$ & 9 & 4 & $15^{*}$ \\
\hline
\end{tabular}

Data are expressed as mean $\pm S D$ and number of patients. ${ }^{*}: p<0.05$, compared to Group $A S, t: p<0.05$, compared to Group BS.

groups during the follow-up time points (data were not presented). The mean intraoperative fentanyl consumption was found lower in the Group BS, compared to Groups AS and C (Table 1) $(\mathrm{p}<0.05)$. The VAS pain scores were significantly lower in both Group BS and Group AS, compared to Group C, immediately after the operation at zero hour (Figure 1) $(\mathrm{p}<0.05)$. In Group AS, VAS scores were also significantly decreased during the first two hours, compared to Group C. At rest periods, VAS scores were similar between groups. Similar incidences of right shoulder pain were observed between groups (9\% in Group BS, 9\% in Group AS and 13\% in Group C, $\mathrm{p}>005)$.

The number of patients needing rescue meperidine and mean doses of meperidine were significantly lower in Group AS, compared to Groups BS and $C$ (Table 2) $(\mathrm{p}<0.05)$. The number of patients requiring rescue metoclopramide was significantly lower in Group AS, compared to Group C (Table 2) $(p<0.05)$. Mean doses of metoclopramide were significantly lower in Groups BS and AS, compared to Group C.

Patient satisfaction was also significantly increased in Groups BS and AS when compared to the control group (Table 3) $(\mathrm{p}<0.05)$. No patient developed any side effect related to levobupivacaine administration.

Table 3. Patient satisfaction

\begin{tabular}{lccc}
\hline & $\begin{array}{c}\text { Group BS } \\
(\mathbf{n = 2 2 )}\end{array}$ & $\begin{array}{c}\text { Group AS } \\
(\mathbf{n = 2 2 )}\end{array}$ & $\begin{array}{c}\mathbf{G r o u p ~ C}^{*} \\
(\mathbf{n = 2 2 )}\end{array}$ \\
\hline Excellent $(\mathrm{n})$ & 20 & 20 & 7 \\
Very good $(\mathrm{n})$ & 1 & 1 & 9 \\
Good $(\mathrm{n})$ & 1 & 1 & 6 \\
\hline
\end{tabular}

${ }^{*} \mathrm{p}<0.05$, compared to other Groups.

\section{Discussion}

This study demonstrates that a combination of incisional and intraperitoneal $0.25 \%$ levobupivacaine administration carried out before or after surgery, can reduce postoperative pain, analgesic and antiemetic consumption, together with improved patient satisfaction. However, administering levobupivacaine before surgery might be advantageous for less intraoperative fentanyl consumption, while levobupivacaine after surgery seems to result in less postoperative rescue analgesic requirement.

Pain after LC arises from the incision sites within the abdominal wall, the pneumoperitoneum and the postcholecystectomy wound within the liver. ${ }^{[9]}$ Factors that may influence the degree of pain after LC include the volume of residual gas, the type of gas used for the pneumoperitoneum, the pressure created by the pneumoperitoneum, the temperature of the insufflated gas, the length of the operation and the volume of the insufflated gas. ${ }^{[10]}$ Since pain after LC is multifactorial, it has been proposed that the combination of incisional and intraperitoneal LA treatment reduces incisional, intraabdominal and shoulder pain in LC. ${ }^{[6]}$ However, there are some factors affecting succesfull analgesic treatment. Until recently, discussed factors related to this issue are doses and concentration of LA, sites (sub-diaphragmatic versus sub-hepatic) and timing of instillation (before versus after surgery) and patient position during the time of instillation (head-down versus supine). ${ }^{[2,11]}$ It has been previously shown that the administration of LA before surgery has been more effective than that after surgery. ${ }^{[4,5]}$ It was suggested that administration of LA at the beginning of the operation served as preemptive analgesia via suppression of central neural sensitization, before the nociceptive stimulus triggered the activation of pain pathways. ${ }^{[2]}$ 
Szem and colleagues ${ }^{[12]}$ reported that intraperitoneal bupivacaine $0.1 \%$ of $100 \mathrm{~mL}$ administered before surgery, offered advantages with respect to postoperative pain after LC only for the first $6 \mathrm{~h}$ without any reduction in the analgesic consumption, compared to the plasebo group. Using lower volume and higher concentration of bupivacaine together with epinephrine in different surgical periods, Pasqualucci and colleagues ${ }^{[4]}$ showed that the administration before versus after surgery of bupivacaine was important to provide satisfactory postoperative pain relief. In that study, combination of the uses of intraperitoneal bupivacaine before and after surgery has maximal pain relief until 24 hour. In another study, Lee and colleagues ${ }^{[13]}$ reported that preoperative somatovisceral or somatic bupivacaine blockade reduced overall incisional pain during the first three postoperative hours, without any significant effect on deep abdominal pain. In our previous study, we used levobupivacaine and found useful effects of combination with incisional and intraperitoneal administration of $40 \mathrm{~mL} \quad 0.25 \%$ levobupivacaine, given immediately after pneumoperitoneum, on pain relief in the early postoperative period and postoperative rescue analgesic requirement, compared to the normal saline group. ${ }^{[8]}$ Pain relief on levobupivacaine administered before surgery was limited to first half an hour postoperatively. In our current study, we investigated whether the timing of combined use of levobupivacaine into the intraperitoneal and incisional ways would result in longer analgesia duration after surgery. We found that patients who received the combination of incisional and intraperitoneal levobupivacaine after surgery had lower VAS pain scores than that of the control group during the first two hours after the surgery and had lower meperidine consumption as well. Using this combination before surgery resulted in decreased fentanyl requirement intraoperatively and duration of pain relief was too short. The decreased postoperative VAS scores in this group were related with paracetamol $1 \mathrm{~g}$ given at the end of surgery together with the higher doses of meperidine, administered to keep VAS scores lower than 4 .

The anesthetic and analgesic requirement could be affected by the systemic effect of LA. ${ }^{[14]}$ In our study, decreased intraoperative fentanyl consumption and postoperative rescue analgesic requirement may also be related to the systemic effect of LB.

Shoulder pain is a frequent complication of laparoscopic surgery with an incidence of $35 \%$ to $60 \%$ in the postoperative period. ${ }^{[15]}$ The proposed mechanism of shoulder pain includes phrenic nerve neurapraxia of short duration, stretching of the subdiaphragmatic fibers by an increased concavity of the diaphragm induced by pneumoperitoneum and reference of pain from the traumatized area. ${ }^{[16]}$ Louizos and colleagues ${ }^{[6]}$ reported that patients with intraperitoneal levobupivacaine had significantly lower incidence of shoulder pain than patients without levobupivacaine (18\% vs $60 \%)$. In our study, the incidence of right shoulder pain was generally low in all groups. The lower incidences of shoulder pain might be due to balanced analgesia and controlled intraperitoneal pressure.

The rescue antiemetic consumptions were also found lower in patients who were given levobupivacaine either before or after surgery compared to control group. The reason of lower antiemetic doses in patients where levobupivacaine was administered might be related to lower requirements of meperidine. This is an important benefit for LC patients since many centers are performing LC as a day-case procedure.

In recently studies, intraperitoneal LA nebulization is found a relatively novel method for pain control after LC. ${ }^{[17,18]}$ This approach can provide uniform dispersion of LA particles thoughout the peritoneal cavity and may increase the duration of the effect of LA.

In conclusion, administering levobupivacaine before surgery might be advantageous for less intraoperative fentanyl consumption, while levobupivacaine after surgery is advantageous for less postoperative rescue analgesic requirement. Further studies are needed to increase the duration of the effect of levobupivacaine.

\section{Conflict-of-interest issues regarding the author- ship or article: None declared.}

Peer-rewiew: Externally peer-reviewed. 


\section{References}

1. $\mathrm{Ng} \mathrm{A}$, Smith G. I: Intraperitoneal administration of analgesia: is this practice of any utility? Br J Anaesth 2002;89(4):535-7.

2. Boddy AP, Mehta S, Rhodes M. The effect of intraperitoneal local anesthesia in laparoscopic cholecystectomy: a systematic review and meta-analysis. Anesth Analg 2006;103(3):682-8.

3. Gupta A. Local anaesthesia for pain relief after laparoscopic cholecystectomy--a systematic review. Best Pract Res Clin Anaesthesiol 2005;19(2):275-92. CrossRef

4. Pasqualucci A, de Angelis V, Contardo R, Colò F, Terrosu G, Donini $A$, et al. Preemptive analgesia: intraperitoneal local anesthetic in laparoscopic cholecystectomy. A randomized, double-blind, placebo-controlled study. Anesthesiology 1996;85(1):11-20. CrossRef

5. Cantore F, Boni L, Di Giuseppe M, Giavarini L, Rovera F, Dionigi G. Pre-incision local infiltration with levobupivacaine reduces pain and analgesic consumption after laparoscopic cholecystectomy: a new device for day-case procedure. Int J Surg 2008;6 Suppl 1:S89-92. CrossRef

6. Louizos AA, Hadzilia SJ, Leandros E, Kouroukli IK, Georgiou LG, Bramis JP. Postoperative pain relief after laparoscopic cholecystectomy: a placebo-controlled double-blind randomized trial of preincisional infiltration and intraperitoneal instillation of levobupivacaine $0.25 \%$. Surg Endosc 2005;19(11):1503-6. CrossRef

7. Cavaliere F, Mascia L, Terragni P. Year in review in Minerva Anestesiologica, 2008. Minerva Anestesiol 2009;75(3):163-7.

8. Alper I, Ulukaya S, Ertuğrul V, Makay O, Uyar M, Balcioğlu T. Effects of intraperitoneal levobupivacaine on pain after laparoscopic cholecystectomy: a prospective, randomized, double-blinded study. Agri 2009;21(4):141-5.

9. Barczyński M, Konturek A, Herman RM. Superiority of preemptive analgesia with intraperitoneal instillation of bupivacaine before rather than after the creation of pneumoperitoneum for laparoscopic cholecystectomy: a randomized, double-blind, placebo-controlled study. Surg Endosc 2006;20(7):1088-93. CrossRef

10. Maestroni U, Sortini D, Devito C, Pour Morad Kohan Brunaldi F, Anania G, Pavanelli L, et al. A new method of preemptive analgesia in laparoscopic cholecystectomy. Surg Endosc 2002;16(9):1336-40. CrossRef

11. Papadima A, Lagoudianakis EE, Antonakis P, Filis K, Makri I, Markogiannakis $\mathrm{H}$, et al. Repeated intraperitoneal instillation of levobupivacaine for the management of pain after laparoscopic cholecystectomy. Surgery 2009;146(3):475-82. CrossRef

12. Szem JW, Hydo L, Barie PS. A double-blinded evaluation of intraperitoneal bupivacaine vs saline for the reduction of postoperative pain and nausea after laparoscopic cholecystectomy. Surg Endosc 1996;10(1):44-8. CrossRef

13. Lee IO, Kim SH, Kong MH, Lee MK, Kim NS, Choi YS, Lim SH. Pain after laparoscopic cholecystectomy: the effect and timing of incisional and intraperitoneal bupivacaine. Can J Anaesth 2001;48(6):545-50. CrossRef

14. Ben-Shlomo I, Tverskoy M, Fleyshman G, Cherniavsky G. Hypnotic effect of i.v. propofol is enhanced by i.m. administration of either lignocaine or bupivacaine. $\mathrm{Br} J$ Anaesth 1997;78(4):375-7. CrossRef

15. Joris J, Thiry E, Paris P, Weerts J, Lamy M. Pain after laparoscopic cholecystectomy: characteristics and effect of intraperitoneal bupivacaine. Anesth Analg 1995;81(2):379-84.

16. Mouton WG, Bessell JR, Otten KT, Maddern GJ. Pain after laparoscopy. Surg Endosc 1999;13(5):445-8. CrossRef

17. Kahokehr A, Sammour T, Soop M, Hill AG. Intraperitoneal use of local anesthetic in laparoscopic cholecystectomy: systematic review and metaanalysis of randomized controlled trials. J Hepatobiliary Pancreat Sci 2010;17(5):637-56. CrossRef

18. Ingelmo PM, Bucciero M, Somaini M, Sahillioglu E, Garbagnati $A$, Charton $A$, et al. Intraperitoneal nebulization of ropivacaine for pain control after laparoscopic cholecystectomy: a double-blind, randomized, placebo-controlled trial. $\mathrm{Br} J$ Anaesth 2013;110(5):800-6. CrossRef 